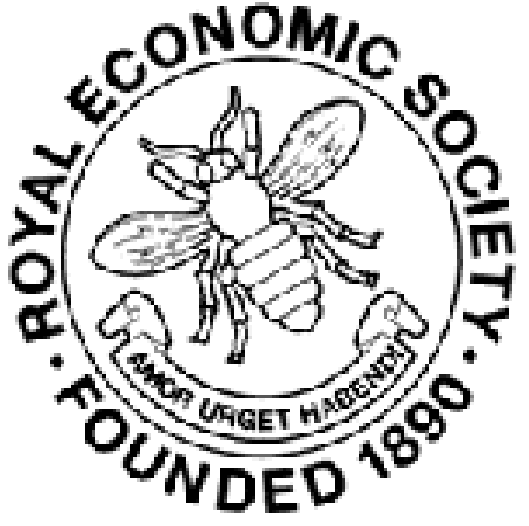

The Results of the Measures Taken in Hungary for the Development of Industry Author(s): Alexander de Hollan

Source: The Economic Journal, Vol. 21, No. 81 (Mar., 1911), pp. 37-52

Published by: Wiley on behalf of the Royal Economic Society

Stable URL: http://www.jstor.org/stable/2222065

Accessed: 27-06-2016 02:34 UTC

Your use of the JSTOR archive indicates your acceptance of the Terms \& Conditions of Use, available at

http://about.jstor.org/terms

JSTOR is a not-for-profit service that helps scholars, researchers, and students discover, use, and build upon a wide range of content in a trusted digital archive. We use information technology and tools to increase productivity and facilitate new forms of scholarship. For more information about JSTOR, please contact support@jstor.org.

Royal Economic Society, Wiley are collaborating with JSTOR to digitize, preserve and extend access to The Economic Journal 


\section{THE RESULTS OF THE MEASURES TAKEN IN HUNGARY FOR THE DEVELOPMENT OF INDUSTRY.}

THE economic conditions of Hungary are of a peculiar character. The geographical situation and the climate of that country, as well as the distribution and inclinations of its population, render it a favourable field for the development alike of agriculture and industry. Yet, whereas its agricultural activity has continuously progressed, and is still progressing, in a most satisfactory manner, its industry seems to have escaped the influence of the great wave of industrial activity sweeping over Western Europe. This is true even of districts which an unusual combination of favourable circumstances (presence of raw materials and fuel, cheapness of labour, etc.) seems to mark as peculiarly fitted to be industrial centres. As a consequence the import of manufactured articles is continually on the increase, a fact that unfavourably influences the balance of foreign trade.

The recognition of this anomaly led to the conviction that the future development of the country depended primarily on a development, on a modern basis, of its industry, and resulted in a determination that the State should be responsible itself for the work of guiding and supporting the development of industrial activity.

Before 1861, the support of the State was confined to indirect grants of money, which were given only to further cottage industry and handicrafts.

The systematic support of manufacturing industry dates from 1861, Act XLIV. This Act guaranteed a certain, somewhat insignificant exemption from taxation, to newly-established factories supplied with all the latest triumphs of technical science. The Act had but little effect in developing industry; yet, as it proved of service, its provisions were added to by a new Act passed in 1890 .

However, during the years immediately succeeding the passing 
of the latter Act, it was seen that the favours granted thereby were insufficient to further a rapid development of industry; and Act XLIX of 1899, which superseded Act XIII of 1890, considerably extended the field covered by the favours, and, in addition to manufacturing industry, included in its provisions independent craftsmen (Kleingewerbetreibende), or, rather, the guilds or co-operations formed by the latter, as well as cottage and agricultural industry.

In addition to the favours guaranteed by this Act (exemption from payment of taxes and dues), at this period the State appropriated considerable sums-distributed in the form of grants or "subventions" - for the direct support of manufacturing industry and independent craftsmen. However, the results produced by the sacrifices made were quite out of proportion to the economic importance of industry as a factor in national life. The insignificant sum voted by Parliament and the favours offered by law proved insufficient for the initiation of a systematic action, on a large scale, for the development of industry, though such measures were imperative, particularly in view of the fact that the backwardness of Hungarian industry was every day becoming more conspicuous as a result of the enormous strides made by the industry of Western Europe.

It was this fact that, in 1902 and 1903, prevailed upon the then Minister of Commerce to ask Parliament to vote a sum far in excess of those previously appropriated for the purpose of developing industry. Parliament accepted his proposals; and this step initiated the really systematic development of industry in Hungary.

The lines of future progress were traced in a work entitled "Memorandum concerning the Development of Industry" (Emlékirat az iparfejlesztésröl), published by the Minister of Commerce, Charles Hieronymi, in 1904. The Memorandum dealt with the importance of the question of development of industry, and, after enumerating all the measures required to further the three branches of industrial production (cottage industry, handicrafts, and manufacturing industry), treated of the fundamental principles to be followed in solving the problems connected with the development and encouragement of industrial activity. This Memorandum was taken as the basis of Act III of 1907, which amended, or rather replaced, Act XLIX of 1899 ; for it endeavoured to put into a more practicable form the guiding principles of the latter, and to do away with the principal defects of the same referred to below. 
In addition to the branches of industry enumerated by name in the Act, only those could participate in the favours granted by the State which were engaged in producing articles that had not been manufactured in the country before the Act came into force. Consequently, where there was already in existence an industrial establishment engaged in the production of any particular article, no new factory producing the same could be given a share in the favours granted by the State, even though the output of those already in existence was quite unable to satisfy the requirements of the country. It is true, indeed, that the enumeration of the branches of industry entitled to favours did not do away altogether with this evil: on the other hand, the nature of things rendered an exhaustive computation unfeasible, and it was out of the question to keep pace with the change in economic conditions. Furthermore, the Act made no provision for the protection, consolidation and expansion of the industry already in existence, for no favours could be granted to factories extending their sphere of activity, or to public workshops for the encouragement of cottage industry and handicrafts; yet the development and protection of factories already working is probably of more importance even than the establishment of new ones. The Act, besides, contained no provisions for grants of money such as had previously been made, the regulation of which by law was particularly desirable : other omissions were measures for procuring all articles required in Hungary (this to protect the home industry already in existence) and for employing native workmen; again, there were no regulations referring to expropriations for industrial purposes, to the favours to be granted by parishes and municipalities, etc.

These facts were all taken into consideration when drafting Act III of 1907, still in force, which is divided into two parts(a) that dealing with the favours (concessions) to be granted to home industry, and (b) that treating of public contracts.

The six main points contained in the first part are :-

(1) Exemption from taxation and dues (for a period not exceeding 15 years), and from road rates (for 15 years).

(2) Reduced rates for railway transport and concessions relating to customs and excise duties and to expropriation (valid for a period of 15 years).

(3) The delivery of industrial salt (a monopoly of the State) at a price below that usually charged.

(4) The encouragement of the building of workmen's dwellings. 
(5) The development of industry by a guarantee that all public contracts shall be placed with Hungarian firms.

(6) The encouragement of industry by direct grants of money (subsidies).

One of the objects of the Act is to further the establishment of factories engaged in the production of articles not hitherto manufactured in the country, or of such the greater part of which have hitherto been imported from abroad, or of any such articles the increased production of which general economic interests render desirable. The favours (concessions) have been extended to essential additions to the plant, etc., of factories already in existence, and to public industrial workshops established after the Act came into force, as well as to those parts of industrial establishments supplying electric energy for industrial or agricultural purposes.

The Act contains a special section dealing with grants of money (subsidies). This section (clause) says that, in cases where general economic interests render the establishment, expansion, or continuation in working of any particular industrial undertaking desirable, with a view to enhancing or ensuring the production of home industry, the Minister of Commerce may grant a subsidy or may further the establishment of such undertakings by making the State an interested party (as shareholder).

The foregoing statements show quite clearly that, as contrasted with previous laws, Act III of 1907 endows the Government with considerable discretionary power as regards the granting alike of favours (concessions) and subsidies: but the action of the Government is made subject to the control of Parliament, to which an annual report of the subsidies and favours granted has to be submitted; and, again, the amount appropriated for this purpose cannot be exceeded without the consent of Parliament having been secured in advance.

The legislative measures above referred to and, in fact, the activity of the State in the field of the encouragement of industry as a whole, has hitherto consisted, generally speaking, of two distinct forms of direct support, viz.:-(a) The granting of various kinds of concessions (favours) guaranteed by law, and (b) the conferring of subsidies (money grants).

To form an adequate conception of the results of the measures taken by a State for the development of industry, we must make a comparison between the effective value represented by the concessions and subsidies granted and the actual development of 
industry during a particular period. We should be guilty, however, of a serious omission if we did not treat of the provisions contained in the second part of Act III of 1907, those, namely, that deal with the indirect support of industry by the State; we refer to one of the most effectual measures for the development of industry, the guarantee that all requirements of the authorities shall be supplied by home industry. By virtue of their manifold character and the great demand involved, the supply of these requirements offers most branches of industry a permanent and natural source of revenue.

There can be no doubt that the most important results of the work of developing Hungarian industry have been achieved in the field of public contracts, as is only natural, seeing that the ensuring of adequately paid work is the best and most infallible means of giving support. That provision of the Act which prevents home industry being ignored without due cause by permitting the acquisition of foreign industrial products only by the consent of the competent Minister acting in conjunction with the Minister of Commerce, affords home industry a protection in many cases far more effectual than any prohibitive customs duties, and one which must without fail be taken into account in judging of the development of that industry.

We have, indeed, no data at our disposal showing the exact percentage of the aggregate number of public contracts (those offered by the State, municipalities and parish councils) given to home industry. However, it should suffice to point out that, in cases where home products of an "adequate" character are to hand, the latter must in all cases be given the preference over foreign products. Consequently, Hungarian factories are not required to compete with foreign ones in respect of price and quality, a course that is reasonable enough in the case of branches of industry the introduction of which is a matter of some difficulty. One fact I may mention is, that, of the aggregate sum of $27 \frac{1}{2}$ millions of crowns (Hungarian) appropriated by State authorities, offices and institutes for public contracts, no less than $24,800,000$ crowns were paid for articles produced in Hungary : consequently, here the percentage of goods of foreign origin was a very insignificant one.

The beneficial effect of public contracts on the development of industry is best proved by the fact that during the last three decades no less than 40 new factories have been established, and several others have considerably enlarged their plant and expanded 
their sphere of activity. The largest metal industry and textile factories, too, owe their origin to the guarantees regarding public contracts.

The effect produced by the provisions relating to public contracts may be said to be a universal one : numerous manufacturers and independent craftsmen (master workmen) have the orders placed with them by the State and municipal authorities to thank for securing work that enables them to thrive and prosper.

In order to illustrate the results of the direct activity of the State in the cause of the development of industry, we must treat separately of manufacturing industry, independent craftsmen, and cottage industry.

The Act dealing with the development of industry contains special provisions imposing upon Government the duty of supporting independent craftsmen and cottage industry. This is done principally by the supply of up-to-date machinery; though Government does not fight shy of granting subsidies to the cooperations of independent craftsmen (master workmen).

When treating of manufacturing industry, we shall first of all give the results attained by the guaranteeing of favours (concessions), and then pass on to show those produced by grants of money.

As regards the State favours (concessions) guaranteed by Act III of 1907, we may form an opinion of their extent from the fact that they vary between 17 and 30 per cent. of the net profits of the undertaking in question, the percentage depending upon whether the said concessions are enjoyed wholly or only in part.

Between the years 1881 and 1909, the granting of such concessions resulted in the establishment of new factories, produced extensions of factories already in existence, or furthered the progress of older factories, as shown below :-

\begin{tabular}{|c|c|c|c|}
\hline $\begin{array}{l}\text { On basis of Act XLIV of } 1881 \\
\text { On basis of Act XIII of } 1890 \\
\text { On basis of Act XLIX of } 1899 \\
\text { On basis of Act III of } 1907 \ldots\end{array}$ & $\begin{array}{l}\text { ew factories. } \\
280(227) \\
360(177) \\
198(28) \\
124(38)\end{array}$ & $\begin{array}{c}\text { Extension of } \\
\text { premises, etc. } \\
4 \\
13 \\
26 \\
22\end{array}$ & $\begin{array}{l}\text { Older factories } \\
195(75) \\
200 \\
13 \\
12\end{array}$ \\
\hline & $962(470)$ & 65 & $420(140)$ \\
\hline
\end{tabular}

The numbers in brackets refer to agricultural distilleries-i.e., of 962 new factories 470 , and of 420 older factories 140 were agricultural distilleries. These figures, therefore, show that the effect of the first two Acts on industry proper was an insignificant 
one, for the concessions (favours) granted thereby were taken advantage of for the most part by agricultural distilleries.

Consequently, the favours offered by these Acts proved inadequate to overcome the difficulties connected with the establishment of factories: and for this reason it was not until more considerable concessions and the grant of direct subsidies had been guaranteed by the later Acts, that Hungarian and foreign capitalists could be prevailed upon to invest their money in the foundation of industrial undertakings.

It was the State concessions guaranteed by Act XLIX of 1899 that brought into being the largest number of new factories (except agricultural distilleries). Taking the various branches of industry separately, the figures were as follows :-

$\begin{array}{lcccc}\text { Spinning and weaving industry } & \ldots & 45 \\ \text { Chemical industry } & \ldots & \ldots & \ldots & 34 \\ \text { Iron industry } \ldots & \ldots & \ldots & \ldots & 19 \\ \text { Machine industry } & \ldots & \ldots & \ldots & 18\end{array}$

The numbers of factories established as a result of Act III of 1907 (up to the close of 1909) were :-

\begin{tabular}{|c|c|c|}
\hline ng and weav & industry & \\
\hline Chemical industry & $\ldots$ & \\
\hline Iron industry & $\ldots$ & \\
\hline
\end{tabular}

If we take the aggregate number of new factories established, we shall find that the greatest proportion is represented by the above three branches of industry (weaving and spinning, 113; chemical industry, 96 ; iron industry, 70)-a circumstance explained by the fact that these branches of industry are, relatively speaking, the least highly developed in the country, as the home production in these branches is, in proportion to others, least able to supply the demand.

Taking as our basis the annual average, Act III of 1907 has produced the largest number of new factories, for, whereas in the first three periods the annual average was only 31 , during the fourth period (two years in all) the annual average has been 43 . Besides the greater extent of the concessions granted by the said Act, this fact is due to the action of the Government in giving considerable subsidies and gifts of machinery with a view to furthering the establishment of new factories.

Subsidies are generally given by the Ministry of Commerce to provide for the establishment of new factories of importance economically, to assist factories already in existence, to make essential additions to their premises, plant, etc., and for the support of co-operations of independent craftsmen, under- 
takings for the encouragement of cottage industry, and committees and societies working for the furtherance of industrial objects. Gifts of machinery are made to independent craftsmen, to people engaged in cottage industry, and, in cases where a moderate extension of premises, plant, etc., is contemplated, to factories of medium size.

We find the first traces of subsidies being given by Government as far back as 1868 :-

The sums appropriated for this purpose were :-Between 1868 and $1880,420,414$ crowns, 86 fillér; between 1880 and 1890, $1,259,530$ crowns, 24 fillér. Most of this money was, however, given to support cottage industry, handicrafts, and independent craftsmen (master workmen).

Factories received State favours (concessions) only.

Between 1890 and 1899 the sums appropriated for subsidies increased enormously from year to year : during this period an aggregate of 4,386,412 crowns, 52 fillér (an annual average of 487,379 crowns) was devoted to this purpose.

The rapid increase in this field dates from 1899, the year in which the measures for the development of industry began to assume a more serious aspect, their scope being at that time extended considerably. Between this year (1899) and 1906, roughly speaking, 16 millions of crowns, and between 1907 and $1909,19,800,000$ crowns were distributed under the head of subsidies.

We must not omit to mention the fact that the subsidies actually voted, a great part of which are not distributed until the following years, are considerably in excess of the sums quoted above; e.g., between 1900 and 1906, the aggregate of the subsidies voted amounted to $29,600,000$ crowns, between 1907 and 1909 , to $38,400,000$ crowns.

The moneys referred to above were devoted, partly to the support of manufacturing industry, partly to the assistance of independent craftsmen, or to the encouragement of industry in other ways.

Table $A$ (see below) will give the reader an idea of the vast sums devoted between 1899 and 1909, in the form of subsidies, to the support of manufacturing industry, and of the results achieved (by the end of 1909). 


\begin{tabular}{|c|c|c|c|c|c|c|c|c|c|c|c|c|}
\hline 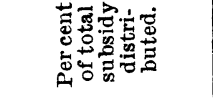 & $\begin{array}{cc}0 & 0 \\
8 & \vdots \\
0\end{array}$ & М̈ & $\dot{0} \mid$ & $\overrightarrow{0}$ & 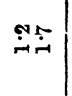 & $\ddot{n}$ & 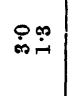 & $\stackrel{\infty}{\ddot{\sigma}}$ & 111 & 1 & 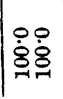 & $\mid \begin{array}{l}0 \\
\dot{0}\end{array}$ \\
\hline 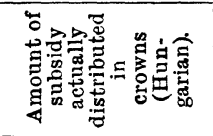 & 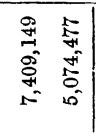 & 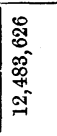 & 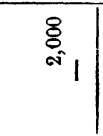 & 豙 & 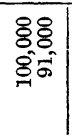 & $\begin{array}{c}8 \\
8 \\
5 \\
\pi\end{array}$ & 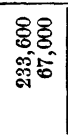 & 总 & 11 & 1 & 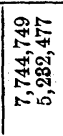 & 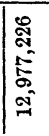 \\
\hline 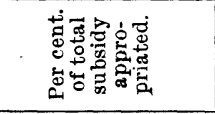 & $\begin{array}{ll}\stackrel{0}{0} & \infty \\
\dot{0} & \dot{8}\end{array}$ & $\dot{0}$ & $\overrightarrow{0} 1$ & \% & $\ddot{0}$ & $\stackrel{\rho}{i}$ & 茫节 & $\dot{\dot{\omega}}$ & 星: & 足 & 送家 & 畺 \\
\hline 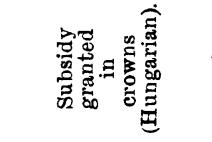 & 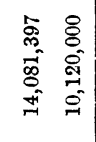 & 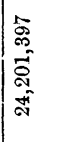 & $\begin{array}{l}8 \\
8 \\
\cong 1\end{array}$ & 总 & 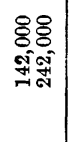 & $\begin{array}{l}8 \\
8 \\
\text { क్ } \\
0\end{array}$ & $\begin{array}{l}88.8 \\
80 \\
\text { เి. }\end{array}$ & $\begin{array}{l}8 \\
8 \\
0 \\
0 \\
10\end{array}$ & 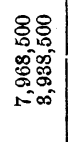 & 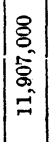 & 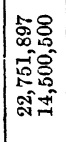 & 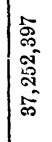 \\
\hline 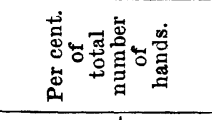 & $\dot{0} \overrightarrow{\dot{i}}$ & ì & $\div 1$ & 0 & $\stackrel{\infty \infty}{\sim} \underset{\sim}{\infty}$ & $\stackrel{\infty}{=}$ & Pit on & 我 & ํ. & 官 & 웅요 & 兽 \\
\hline 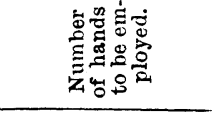 & $\begin{array}{ll}\infty & 0 \\
\infty & \infty \\
\infty & 0 \\
\pm & 0 \\
= & 0\end{array}$ & 量 & 是1 & 9 & 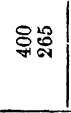 & 18 & 悉茴 & 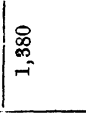 & 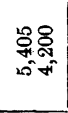 & $\begin{array}{l}0 \\
0 \\
0 \\
\circ\end{array}$ & 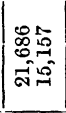 & 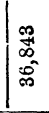 \\
\hline 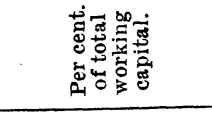 & 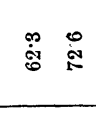 & : & 11 & 1 & $\stackrel{m}{90}$ & $\vec{r}$ & 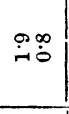 & 苛 & 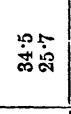 & $\mid \begin{array}{l}\infty \\
\dot{\omega} \\
\infty\end{array}$ & 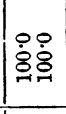 & 㝱 \\
\hline 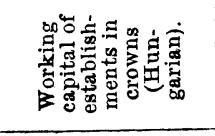 & 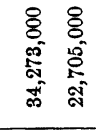 & $\mid \begin{array}{l}8 \\
8 \\
\infty \\
5 \\
0 \\
0 \\
0\end{array}$ & 11 & 1 & 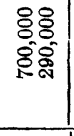 & 咅 & 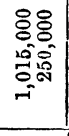 & $\begin{array}{c}8 \\
8 \\
0 \\
0 \\
-1 \\
-1\end{array}$ & 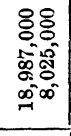 & 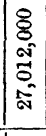 & 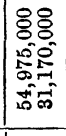 & $\mid \begin{array}{l}8 \\
8 \\
0 \\
0 \\
0 \\
0 \\
8\end{array}$ \\
\hline 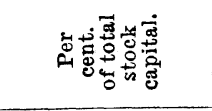 & $\begin{array}{l}\infty \\
\stackrel{8}{8}\end{array}$ & 思 & 11 & 1 & $\dot{\varphi} \ddot{\dot{0}}$ & $\dot{0}$ & $\underset{\dot{N}}{*}$ & $\stackrel{5}{-1}$ & 落品 & $\stackrel{P}{\dot{\mathscr{d}}}$ & 잉요 & $\dot{0}$ \\
\hline 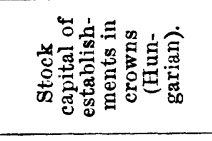 & 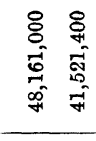 & 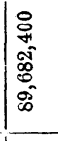 & 11 & 1 & 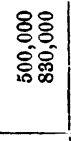 & $\mid \begin{array}{l}8 \\
0 \\
0 \\
0 \\
0 \\
0-1\end{array}$ & $\begin{array}{l}80 \\
80 \\
\infty \\
0 \\
0 \\
= \\
=\end{array}$ & $\mid \begin{array}{l}8 \\
0 \\
\infty \\
0 \\
0 \\
0 \\
0 \\
0\end{array}$ & 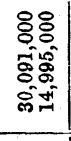 & $\left|\begin{array}{c}8 \\
0 \\
0 \\
0 \\
0 \\
0.0 \\
01\end{array}\right|$ & 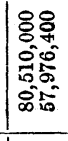 & 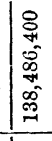 \\
\hline 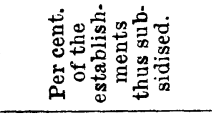 & 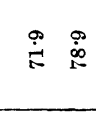 & $\overrightarrow{i p}$ & $\stackrel{0}{0} 1$ & $\ddot{\theta}$ & $\stackrel{+\infty}{\sim}$ & $\stackrel{\leftrightarrow}{-}$ & 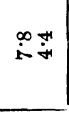 & \% & 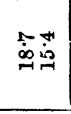 & 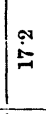 & 迥 & $\dot{0}$ \\
\hline 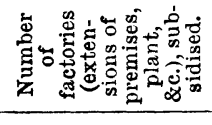 & 品 & 哭 & -1 & 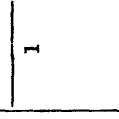 & लล & $*$ & 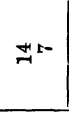 & ส & ఝై & $\stackrel{\infty}{\infty}$ & 票怘 & 庐 \\
\hline 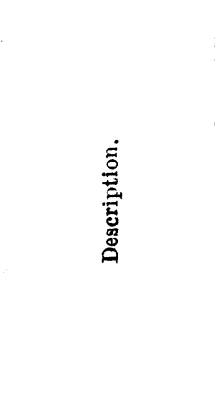 & 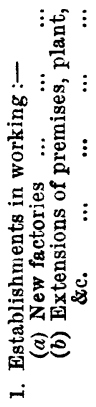 & $\begin{array}{c}\vdots \\
\vdots \\
\vdots \\
\vec{J} \\
\text { 递 }\end{array}$ & 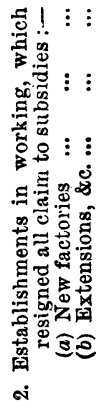 & 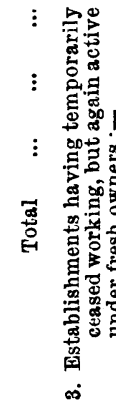 & 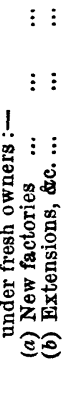 & 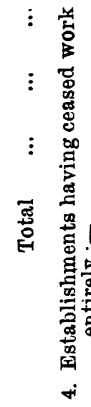 & 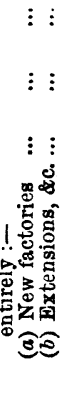 & 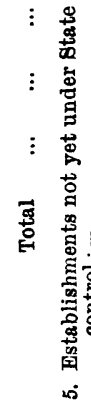 & 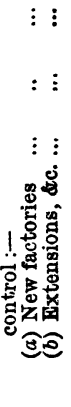 & $\begin{array}{c}\vdots \\
\vdots \\
\vdots \\
\underset{\vec{\omega}}{\overrightarrow{0}}\end{array}$ & 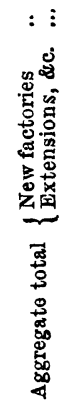 & 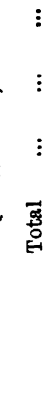 \\
\hline
\end{tabular}


During the period referred to altogether 181 new factories were established and additions made to factories in 156 cases, with the help of the State.

These factories were distributed among the various branches of industry as follows :-

\begin{tabular}{|c|c|c|c|c|}
\hline & & & $\begin{array}{c}\text { New } \\
\text { factories. }\end{array}$ & $\begin{array}{c}\text { Additions } \\
\text { (extensions) }\end{array}$ \\
\hline Iron and metal industr & $\ldots$ & $\ldots$ & 34 & 17 \\
\hline Machine industry ... & & & 6 & 12 \\
\hline Pottery, earthenware, & nd glass & 8 industry & 9 & 13 \\
\hline Wood industry $\quad \ldots$ & $\ldots$ & $\ldots$ & 17 & 11 \\
\hline Weaving industry .... & $\ldots$ & $\ldots$ & 4 & 9 \\
\hline Spinning industry .... & $\ldots$ & $\ldots$ & 53 & 64 \\
\hline Clothing industry .... & $\ldots$ & $\ldots$ & 17 & 11 \\
\hline $\begin{array}{ll}\text { Paper industry } & \ldots .\end{array}$ & $\ldots$ & $\ldots$ & 5 & 3 \\
\hline Food industry & $\ldots$ & $\ldots$ & 15 & 6 \\
\hline Chemical industry ... & $\ldots$ & $\ldots$ & 21 & 9 \\
\hline Reproductive art ... & $\ldots$ & $\ldots$ & - & 1 \\
\hline & & $\ldots$ & $\overline{181}$ & 156 \\
\hline
\end{tabular}

As will be seen, for the reasons put forward above, the greater part of these factories are engaged in textile and iron industry.

In return for the subsidies voted, it was stipulated that a capital of, altogether, 138,000,000 crowns should be invested, and 36,843 hands permanently employed.

The results of the measures taken to develop industry are shown in a favourable light by the reports of the officials deputed to control the use made of the subsidies between 1899 and 1909 : the data contained in the same prove that, at the time the work of control was carried out in 1909, the amount of capital invested was not $77,000,000$ crowns, as stipulated, but, roughly, $106,000,000$ crowns, and that the number of hands employed exceeded that stipulated $(22,361)$ by 9,039 .

Between 1899 and 1901, in addition to the subsidies in money referred to above, 404 factories received gifts of machinery of an aggregate value of $4,800,000$ crowns. Here, too, the results achieved were relatively of extreme significance, for only in 14 cases had machines (representing a total value of 114,000 crowns) to be forfeited (taken back) for non-fulfilment of the conditions stipulated, or owing to the establishment in question being closed.

As regards the machinery supplied between 1899 and 1909 to independent craftsmen (master workmen) and the results achieved thereby, the table $(B)$ to be found below, containing the data comprised in the reports of the controlling officials, shows us how things stood at the close of 1909 :- 


\section{TABLE B.}

Concerning the machinery supplied to independent craftsmen (master workmen) between 1899 and 1909, and the results shown at the close of 1909.

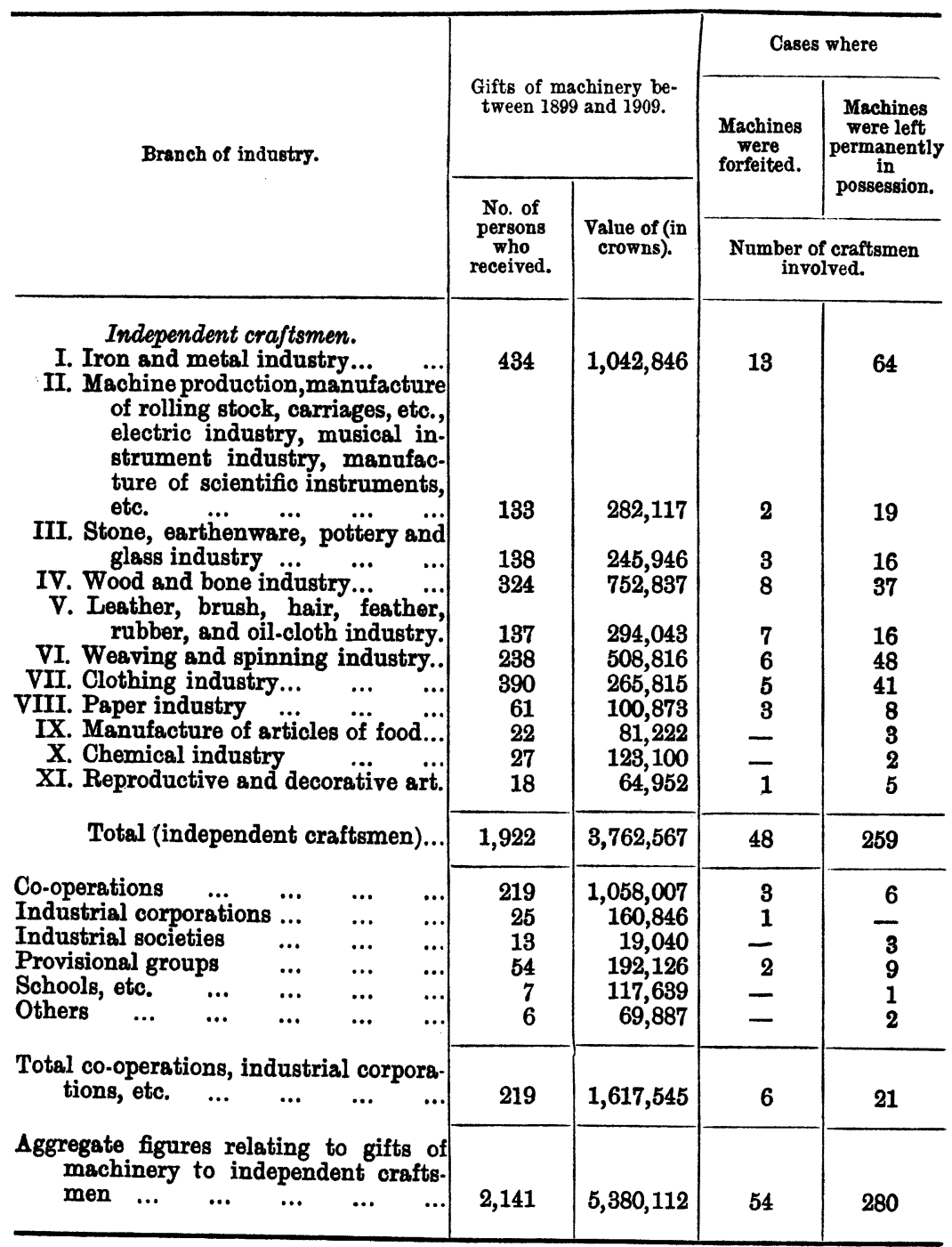

According to the above data, 1,922 independent craftsmen were supplied with machines of the aggregate value of $3,762,567$ crowns. In 48 cases the machines had to be declared forfeited, because the craftsmen in question were unable to use them or keep them permanently working. 
A considerable sum is represented by the machines supplied to co-operations, too-219 cases in all, the machines involved being of a total value of 1,058,007 crowns. Of the aggregate number of cases where machinery was supplied, $2 \cdot 6$ per cent. have had to forfeit the machines, while in 13.1 per cent. the machines have passed into the permanent possession of the recipients. The rest are still under control : and, according to the reports of the respective inspectors of industry and chambers of commerce, the majority of the machines are being used with favourable results.

The figures above quoted show the measures taken by the State for the development of industry to have been remarkably successful, the proportion of failures being a very small one, whether we take manufacturing industry or independent craftsmen. However, these data are in themselves insufficient to enable us to judge clearly of the results : and the picture thus offered might lead to incorrect conclusions. To avoid such an eventuality, we must investigate the said results from the point of view of the actual development of industry, a correct estimation of which may perhaps be formed by a comparison of the respective outputs of two particular years, and by quoting the data referring to the foreign trade of the country.

We have no detailed figures but those referring to the production of manufacturing industry : for that reason it is with the latter that we intend principally to concern ourselves.

The statistics of the years 1898 and 1906 may serve as a guide in our investigation of the development of the production of manufacturing industry.

In order to determine the actual results of the measures taken for the development of industry, we should prefer to have at our disposal the data referring to the production of Hungarian manufacturing industry in 1909 ; in fact, we ought really to wait a few years more if we would observe the effective results of the secrifices made by the State, and would express the same in figures reflecting the exact state of affairs.

However, we believe that even the statistical data of 1906 will offer a suitable basis for the making of comparisons : development in the field of industry does not take place by leaps and bounds; and in the present case we are endeavouring to determine, not absolute, but relative results.

The development of the production of our manufacturing industry between 1898 and 1906 is shown in the following table $(C):-$ 


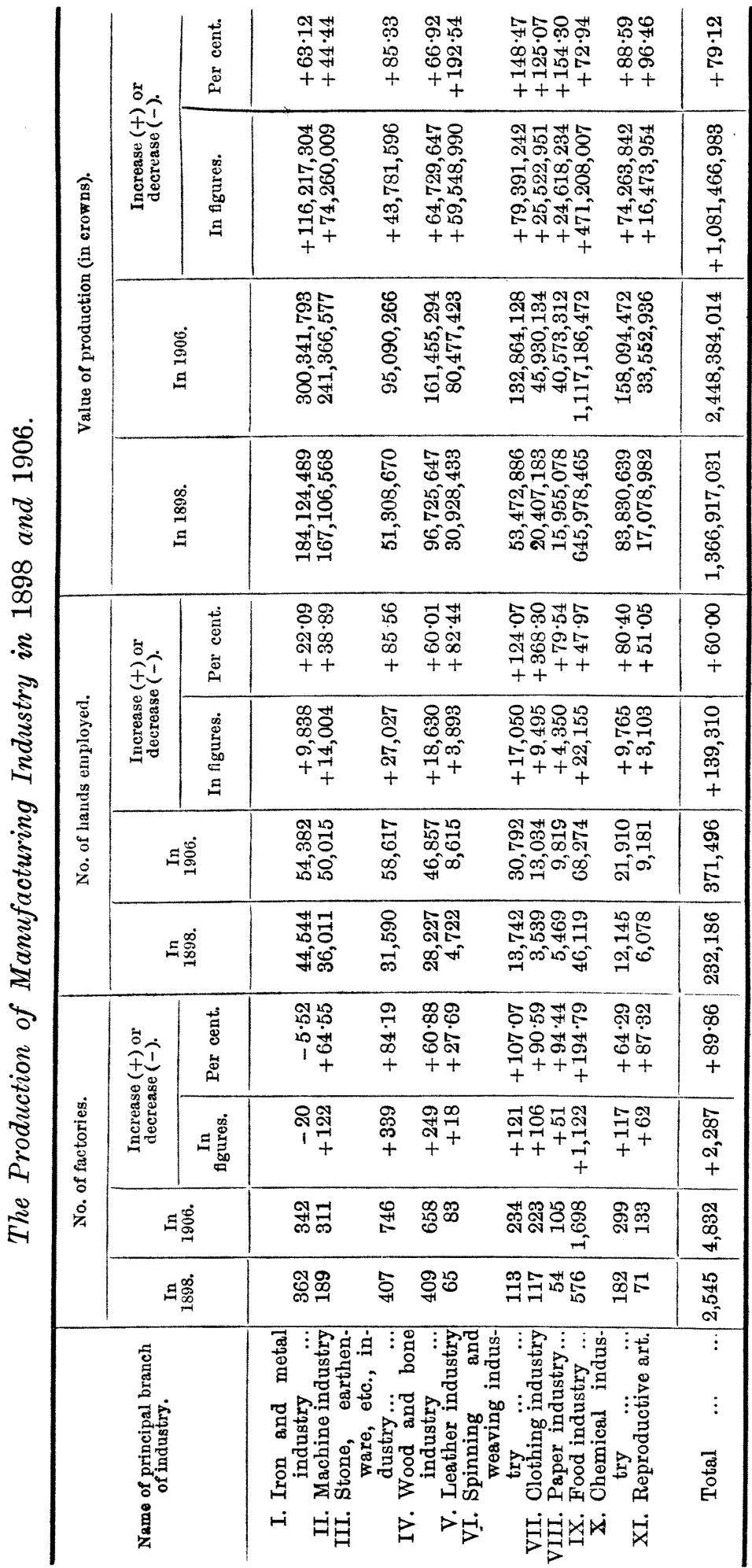

No. 81.- -voL. XXI.

This content downloaded from 128.163.2.206 on Mon, 27 Jun 2016 02:34:39 UTC All use subject to http://about.jstor.org/terms 
According to the above table the number of factories had increased by 2,287 , or about 90 per cent., the value of the annual production by 1,081,000 crowns, or 79 per cent. If we examine the absolute figures relating to the increase of the value of the annual production, we shall see that the largest increase (471 millions of crowns) took place in the case of factories employed in the production of articles of food; the next largest is that of the iron industry (116 millions), which is followed by the weaving and spinning industry (79 millions), the machine industry and the chemical industry (74 millions each). In the first-named branch the largest increase is shown by the milling industry, in the iron industry by the iron foundries. Neither the mills nor the iron foundries received any support from the State. On the other hand, of the sum (shown above) of 22,751,897 crowns appropriated for subsidies, 57 per cent. fell to the weaving and spinning industry, 12 per cent. to the metal and iron industry, 7.6 per cent. to the clothing industry, 5.9 per cent. to the chemical industry, and proportions varying between 1.2 and 4.1 per cent. to the other branches of industry. A comparison of the annual increase in production with the distribution of the subsidies granted by the State leads to the conclusion that the measures taken by the Government for the development of industry dealt with above have not got at the root of the matter, or rather do not play a predominant part in the work of industrial development.

It is undeniable, however, that in the case of certain branches of industry, these measures have produced remarkable results: e.g., in the weaving and spinning industry the value of the annual production, during the period referred to above, increased by about $80,000,000$ crowns. Now, without the assistance of Government and its endeavours to further industrial development, in most cases the increased production would have been out of the question, owing to the competition of the advanced textile industry of Austria.

We shall arrive at the same results if we examine the statistics relating to our foreign trade.

The data referring to the years 1906-1909 will be found below :-

Manufactures.

$\begin{array}{cccc} & \text { Imports. } & & \text { Exports. } \\ 1906 & 1,033,934,000 & \text { (in tons). } & \\ 1907 & 1,101,920,000 & & 525,637,000 \\ 1908 & 1,033,633,000 & & 565,288,000 \\ 1909 & 1,137,162,000 & & 620,654,000 \\ & & \end{array}$


According to these figures the development of our industry is only just managing to keep pace with the increased demand; in fact, in the case of some of the least advanced branches of industry (textile, iron industry), the continuous increase in imports seems to prove that these branches are not developing in proportion to the increased demand for the articles they produce.

To sum up what we have said: the peculiar economic conditions of Hungary, her national and financial position render the development of Hungarian industry extremely desirable ; however, the method of concessions and subsidies hitherto employed cannot be said to be adequate for a development of industry of any particular significance. What is wanted is a series of measures that will guarantee the unhindered progress of the country's industry and enhance its ability to compete with and hold its own against that of Austria, which is well advanced and produces far more than is sufficient to supply the demand of that country.

To determine the actual results of the support offered by the State to independent craftsmen, we have need of statistical data, at least with regard to the increase in the number of such craftsmen. We have at our disposal data of this kind only concerning the year 1900-or, rather, we shall have them after the statistics connected with the census of 1910 have been elaborated.

The only guide we have is that offered by the data furnished by certain industrial corporations.

The members of these corporations are for the most part engaged in the clothing industry. Between $1901(38,443)$ and $1906(58,112)$, the number of these members increased by about 50 per cent.

The number of shoemakers rose in the same period by 5.5 per cent. (in 1906 they numbered 32,596 ), that of smiths by 38.8 per cent. $(20,596)$, that of master masons by 38 per cent. $(17,171)$; the number of carpenters, builders, painters, and house-painters increased, too, though here the aggregates are smaller.

On the other hand there was a decrease in the number of cobblers, hatmakers, glovers, joiners, pork-butchers, butchers, and bakers.

These data prove quite clearly that, since 1900 , the position of independent craftsmen (master workmen) has scarcely changed at all (i.e., if we take them altogether), as well as that the gifts of machinery to such craftsmen are not calculated to exercise any significant influence on the development of industry.

It is more particularly from the socialistic point of view that 
these measures possess an importance of their own. By doing all they can to protect the generation of craftsmen they help to bridge over the gulf between handicrafts and industry in its widest sense, and facilitate that transition from one to the other which must be the inevitable outcome of the development of technical science.

ALEXANDRE DE HOLLÁN 